\title{
Protein turnover in skeletal muscle of piglets
}

\author{
By B. N. PERRY \\ ARC Meat Research Institute, Langford, Bristol BS ${ }_{1} 8 D Y$
}

(Received 22 February 1973 - Accepted 31 May 1973)

\begin{abstract}
I. Rates of protein synthesis and catabolism were measured in longissimus dorsi and hind-limb muscles of suckling piglets.

2. Half-lives for synthesis and catabolism for mixed sarcoplasmic proteins were 4.8 and $9.4 \mathrm{~d}$ respectively. The corresponding values for mixed myofibrillar proteins were 5.7 and $16.4 \mathrm{~d}$. 3. The half-lives for synthesis of sarcoplasmic proteins were significantly different from those of myofibrillar proteins and were not confounded by contamination of the sarcoplasmic protein fraction with plasma proteins of higher specific activity.

4. Individual myofibrillar proteins were synthesized and catabolized at rates which were not statistically significantly different. Intramuscular connective tissue also appeared to turnover rapidly, the half-life for synthesis being $8 \mathrm{~d}$ and that for catabolism $20 \mathrm{~d}$.

5. Values obtained for the specific radioactivities of aspartate + glutamate in mixed plasma proteins support the view that, in so far as the young of animals larger in mature body size than rats or mice are concerned, muscle assumes a more important role relative to liver in regulating whole body amino acid metabolism.
\end{abstract}

There have been several recent publications on rates of protein turnover in serum, liver, muscle and brain of rats and mice (Waterlow \& Stephen, I968; Garlick, I969; Millward, 1970 a, b; Gan \& Jeffay, 1971; Garlick \& Marshall, 1972). To the author's knowledge, however, no published results exist for rate of turnover of muscle proteins in large animals. Furthermore, many of the reports on rates of synthesis and catabolism of individual muscle proteins are complicated by the problem of amino acid reutilization in muscle (Young, r970). Some results for the young of one large animal, the pig, are presented in this paper in which rates of synthesis $\left(k_{\mathrm{s}}\right)$ and catabolism $\left(k_{\mathrm{c}}\right)$ were measured using an experimental procedure similar to that of Millward (1970 $a, b$ ). In this technique, which largely overcomes the problems associated with amino acid re-utilization, the proteins are labelled by a single injection of $\left[{ }^{14} \mathrm{C}\right] \mathrm{Na}_{2} \mathrm{CO}_{3}$ solution. After isolation and hydrolysis of the protein to be examined the specific radioactivities (a) of incorporated aspartate + glutamate are measured.

Two experiments are reported. In the first, rates of synthesis of myosin, actin, sarcoplasmic and intramuscular connective tissue (IMCT) proteins were measured in 12-d-old piglets. In the second, rates of catabolism were also measured, but in 6-d-old piglets. Various isolation procedures were also compared to determine the effects on the half-lives for synthesis $\left(T_{\mathrm{s}} T_{\frac{1}{2}}\right)$ and catabolism $\left({ }_{\mathrm{c}} T_{\frac{1}{2}}\right)$ of contaminating proteins.

\section{METHODS}

\section{Animals}

Two groups of three male piglets were used for the two experiments. The mean weight of piglets in the first experiment was $3.5 \pm 0.2 \mathrm{~kg}$ at $12 \mathrm{~d}$. Those in the second 
experiment weighed $\mathrm{I} \cdot 2 \pm 0 \cdot \mathrm{I} \mathrm{kg}$ at birth and $3 \cdot \mathrm{I}, 3.6$ and $4.2 \mathrm{~kg}$ respectively, at slaughter, at 7,12 and $15 \mathrm{~d}$ of age. Each group was allowed to suckle the sow and had access to dry piglet feed until immediately before slaughter.

\section{Isotope administration and slaughter of piglets}

Sterile aqueous $\left[{ }^{14} \mathrm{C}\right] \mathrm{Na}_{2} \mathrm{CO}_{3}$ solution (CFA 2; Radiochemical Centre, Amersham, Bucks.) was injected intraperitoneally from weighed syringes. In the first group each animal received $3 \mathrm{mCi}$, in the second $1.2 \mathrm{mCi}$.

Piglets of the first group were killed $\mathrm{I}, 4$ and $7 \mathrm{~d}$ after injection, those of the second group I, 6 and $9 \mathrm{~d}$ after injection. Each piglet was killed by a blow on the skull and severance of the head to allow maximum drainage of blood.

\section{Collection of samples}

Expt I. Longissimus dorsi (LD) and biceps femoris muscles were dissected from the carcass immediately after slaughter, placed in polyethylene bags and stored in ice. IMCT and myofibrillar proteins were prepared from fresh LD muscle. Mitochondria were prepared from fresh biceps femoris muscle by the method of Cheah (1970).

Expt 2. Longissimus dorsi, biceps femoris, semitendinosus, semimembranosus and adductor muscles were dissected from the carcass, trimmed of fat, weighed, chopped finely and mixed well. The latter four hind-limb muscles (HL) (see above) were then pooled for subsequent analysis. Two $10 \mathrm{~g}$ samples of LD and HL were frozen at $-20^{\circ}$. After freeze-drying, these samples were powdered and sampled for composition studies (Helander, 196r). Moisture content was calculated from the equation $\mathrm{H}_{2} \mathrm{O}(\%)=$ I00-7.08 $\times$ protein nitrogen $(\%)(\mathrm{J} . \mathrm{R}$. Bendall, personal communication). Residual fresh muscle was fractionated by the methods described below.

\section{Preparation of protein fractions}

Sarcoplasmic proteins. Muscle was homogenized in 2 vol 20 mM-tris, 2 mM-EDTA for $2 \mathrm{~min}$ at $0^{\circ}$ with a Polytron homogenizer. After centrifugation at $12000 \mathrm{~g}$ for $10 \mathrm{~min}$ at $0^{\circ}$, two $50 \mathrm{ml}$ samples of the supernatant fraction were removed, brought to $\mathrm{pH} 5^{\circ} \mathrm{O}$ with $O^{\circ} \mathrm{I} \mathrm{M}$-acetic acid and incubated at $52^{\circ}$ for $45 \mathrm{~min}$. The denatured sarcoplasmic proteins ( $\mathrm{pH}_{5}$ sarcoplasmic-protein fraction) were separated from contaminating plasma albumin by repeated centrifugation and washing. Trichloroacetic acid (TCA) was then added to the $\mathrm{pH}_{5} .0$ sarcoplasmic-protein pellets and to the original $12,000 \mathrm{~g}$ supernatant fraction (mixed, untreated sarcoplasmic-protein fraction) to a final concentration of $5 \circ \mathrm{g} / \mathrm{l}$. Precipitated proteins were removed, extracted at $70^{\circ}$ for $30 \mathrm{~min}$ with TCA ( $100 \mathrm{~g} / 1)$, dehydrated in acetone, extracted twice with diethyl ether and stored under reduced pressure.

Myofibrillar proteins. These proteins were prepared from the tris-EDTA pellets, after sarcoplasmic-protein extraction, by methods devised in this laboratory (J.R. Bendall \& I. F. Penny, unpublished observations). Essentially the procedure for actomyosin and myosin involved preliminary extraction with $0.5 \mathrm{M}-\mathrm{KCl}$, purification by dialysis, dissociation in the presence of pyrophosphate and $\mathrm{Mg}^{2+}$ and final separation by ultracentrifugation. Actin was obtained by a procedure which dissociated 
actomyosin and depolymerized actin in the presence of ATP and ascorbic acid. Both these procedures have been shown, by sodium dodecyl sulphate-acrylamide gel electrophoresis to yield proteins of high purity.

IMCT. Two different procedures were used. In Expt I the material collected from the homogenizer shaft and blades and that remaining after actin extraction were pooled and homogenized in 100 vol $0 . \mathrm{I} \mathrm{M-KCl}$. After standing for $4 \mathrm{~h}$, the connective tissue sediment was suspended in $\mathrm{I} \mathrm{M}-\mathrm{KCl}$ and extracted overnight at $2^{\circ}$ with stirring. After dehydration in ethanol it was then washed three times with acetone, extracted with TCA $(100 \mathrm{~g} / \mathrm{l})$ at $70^{\circ}$ for $30 \mathrm{~min}$, washed in diethyl ether and stored under reduced pressure.

In Expt 2 the IMCT after extraction with $\mathrm{I} \mathrm{M}-\mathrm{KCl}$ was incubated for $24 \mathrm{~h}$ at $37^{\circ}$ in $250 \mathrm{ml} 100 \mathrm{~mm}-$ sodium phosphate buffer, $\mathrm{pH} \mathrm{7.2,} \mathrm{containing} 0.2 \mathrm{mg}$ trypsin $/ \mathrm{ml}$ (Type III, Bovine Pancreas; Sigma Chemical Co., London) and $5 \mathrm{mg}$ aureomycin/kg (Lederle Co., London). It was then washed six times in cold phosphate buffer to remove trypsin and prepared with lipid solvents as above. This procedure has been shown to yield IMCT of very high purity as judged by hydroxyproline content (Mohr, 1970).

Other protein fractions. In Expt 2, freeze-dried muscle was extracted with I I M-KI, O. I M-sodium phosphate ( $\mathrm{pH}_{7} \cdot 4$ ) according to the method of Helander (1957) to yield KI-soluble protein and stroma-protein fractions. The stroma material was not extracted with TCA but with ethanol-diethyl ether (3:I, v/v) (twice), diethyl ether and acetone. Samples of mixed plasma proteins obtained from heparinized blood collected at slaughter and of mixed mitochondria proteins were extracted with TCA and lipid solvents as described on p. 36 for sarcoplasmic proteins.

\section{Amino acid analysis and isotope assay}

Aspartate + glutamate were obtained from protein hydrolysates by displacement chromatography on Deacidite G-I-P resin (Permutit Ltd, London) (Partridge \& Brimley, 1949). The method of Yemm \& Cocking (1955) was used to estimate concentrations. Radioactivity was measured in a Packard Tricarb Spectrometer (Packard Instruments Ltd, London) using a scintillator based on Triton-toluene. $a$ was calculated as counts $/ 40 \mathrm{~min}$ per $\mu \mathrm{mol}$ aspartate + glutamate. Counting efficiencies were checked with internal standard $\left[{ }^{14} \mathrm{C}\right]$ hexadecane (Radiochemical Centre, Amersham, Bucks.) but, as similar quantities of each protein fraction were subsequently prepared for analysis, this procedure was shown to be routinely unnecessary.

The decay with time of aspartate + glutamate $a$ was used to calculate $k_{\mathrm{s}}$, thereby reducing the effects of amino acid re-utilization (Millward, 1970a). Similarly $k_{\mathrm{c}}$ was calculated from the decay with time of the total activity of aspartate + glutamate, using the values for $a$ and muscle composition (Millward, I970a,b). In the experiments reported here $k_{\mathrm{c}}$ values were determined from the plots of $\log$ (mg $\mathrm{N}$ of fraction/g fresh muscle $\times$ muscle weight $(\mathrm{g}) \times$ relative counts) against time $(\mathrm{d})$. Relative counts were calculated from the $k_{\mathrm{B}}$ values presented in Table $\mathrm{x}$, other values being obtained from the growth curves of muscle-protein fractions in Fig. 2, which were in turn derived from values in Tables 2 and 3 . Half-lives for synthesis $\left({ }_{\mathrm{s}} T_{\frac{1}{2}}\right)$ and catabolism $\left({ }_{\mathrm{c}} T_{\frac{1}{2}}\right)$ 
'Table I. Rate constants $(k)$ and half-lives $\left(T_{\frac{1}{3}}\right)$ of synthesis $(s)$ and catabolism $(c)$ for various protein fractions of longissimus dorsi $(L D)$ and hind-limb $(H L)$ muscles of piglets

\begin{tabular}{|c|c|c|c|c|c|c|c|c|c|c|}
\hline \multirow[b]{3}{*}{ Protein fraction } & \multicolumn{3}{|c|}{$k_{*}$ value $\left(\mathrm{d}^{-1}\right)$} & \multicolumn{7}{|c|}{ Combined results (correlated values) } \\
\hline & \multirow{2}{*}{$\begin{array}{c}\text { Expt I } \\
\text { LD }\end{array}$} & \multicolumn{2}{|c|}{ Expt 2} & \multirow{2}{*}{$\begin{array}{c}k_{*} \\
\left(\mathrm{~d}^{-1}\right)\end{array}$} & \multirow{2}{*}{$\begin{array}{c}\text { SE of } \\
k_{s}^{*}\end{array}$} & \multirow{2}{*}{$\begin{array}{l}{ }_{8} T_{\frac{1}{2}} \\
\text { (d) }\end{array}$} & \multicolumn{2}{|c|}{$k_{\mathrm{e}}\left(\mathrm{d}^{-1}\right)$} & \multicolumn{2}{|c|}{${ }_{\mathrm{c}} T_{\frac{1}{2}}(\mathrm{~d})$} \\
\hline & & $\mathrm{LD}$ & $\mathrm{HL}$ & & & & $\mathrm{LD}$ & $\mathrm{HL}$ & LD & $\mathrm{HL}$ \\
\hline $\mathrm{pH} 5$ sarcoplasmic & - & 0.143 & 0.143 & 0.145 & $\begin{array}{c}0.0073 \\
(6)\end{array}$ & $4 \cdot 78$ & 0.077 & 0.071 & $9^{\circ}$ & $9 \cdot 8$ \\
\hline Actomyosin & $\cdots$ & 0.121 & $0.12 I$ & 0.122 & $\begin{array}{c}0.0038 \\
(6)\end{array}$ & $5 \cdot 68$ & 0.046 & 0.0 .39 & 15.0 & $17 \cdot 7$ \\
\hline Actin & 0.112 & 0.120 & $0 \cdot 3_{3}$ & $0.1 \times 5$ & $\begin{array}{c}0.0079 \\
(8)\end{array}$ & $6 \cdot 03$ & -- & - & - & -- \\
\hline Nyosin & 0.116 & $0 \cdot 116$ & $0 \cdot 157$ & 0.133 & $\begin{array}{c}0.0093 \\
(9)\end{array}$ & $5 \cdot 21$ & -- & - & - & - \\
\hline $\begin{array}{l}\text { Mean of actin and } \\
\text { myosin }\end{array}$ & $0.11_{4}$ & 0.113 & 0.144 & 0.124 & - & 5.59 & $\cdots$ & - & - & - \\
\hline $\begin{array}{l}\text { Intramuscular } \\
\text { connective tissue }\end{array}$ & 0.086 & - & - & 0.086 & $\overline{(3)}$ & 8.07 & 0.035 & 0.031 & $20 \cdot 0$ & 2.0 \\
\hline Stroma & - & 0.109 & 0.110 & 0.109 & $\begin{array}{c}0.012 \\
(5)\end{array}$ & $6 \cdot 33$ & - & - & - & - \\
\hline
\end{tabular}

were derived from the expression $T_{\frac{1}{2}}=0.693 / k$, where $k$ is the rate-constant for synthesis or catabolism. The percentages of myofibrillar protein $\mathrm{N}$ present as myosin and actin were taken for the purposes of this study as being 54 and 22 respectively (J. R. Bendall, personal communication). It is therefore implicit that $k_{\mathrm{s}}-k_{\mathrm{e}}$ measures the rates of net synthesis (i.e. growth) of each of the protein fractions. Furthermore, the aspartate + glutamate composition of each of the individual protein fractions is not required for the calculation of $k_{\mathrm{e}}$ since each protein fraction is considered to have a constant and characteristic amino acid composition.

\section{RESULTS}

The combined results of Expts $\mathrm{I}$ and 2 for the decay in aspartate + glutamate $a$ with time in the actomyosin, actin, myosin and $\mathrm{pH}_{5}$ sarcoplasmic-protein fractions are shown in Fig. $\mathrm{I}$. Although the piglets received large doses of ${ }^{14} \mathrm{CO}_{3}{ }^{2-}$ the absolute count rates were low. This necessitated preparation of large quantities of sample material and counting amino acid samples for comparatively long periods (up to $40 \mathrm{~min} / \mathrm{sample}$ ). Furthermore, in Expt 2 the $a$ values were considerably higher than in Expt I. However, when corrected for differences in isotope dosage, size of animal and counting procedure, good agreement was obtained between the results of the two experiments (Fig. I and Table $\mathrm{I}$ ).

The factors, $\times 0.67$ (actin) and $\times 0.25$ (myosin), used in Fig. I allow the reader to easily identify results obtained for each protein fraction. They do not influence the results or conclusions subsequently drawn from them. For example, the values for 


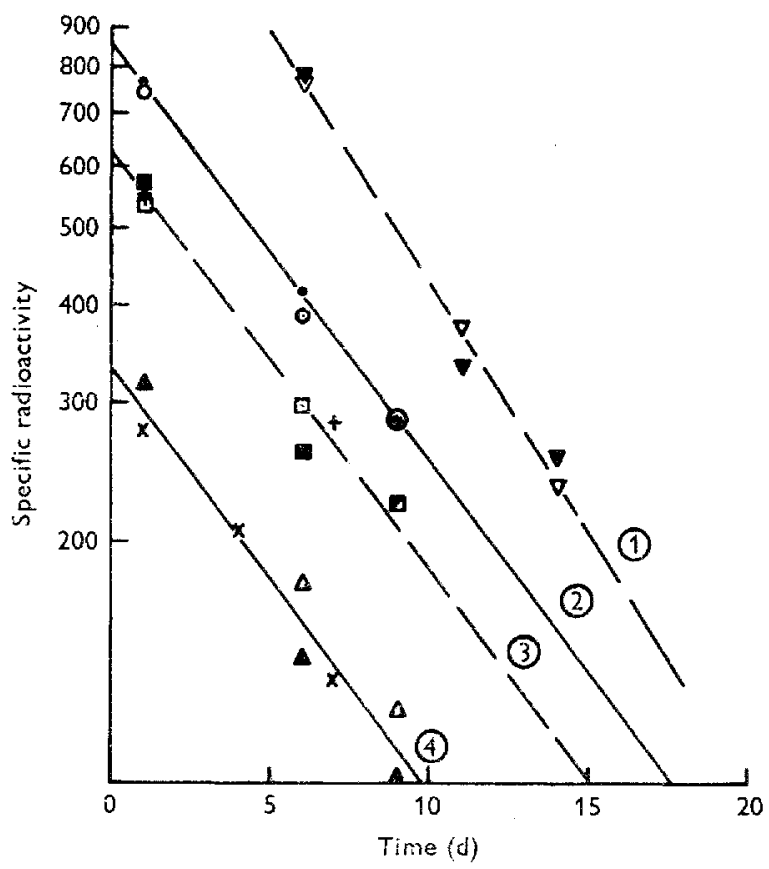

Fig. I. Combined results of Expts I and 2 for the decay of specific radioactivity $(a)$ with time in actomyosin, actin, myosin and $\mathrm{pH}_{5}$ sarcoplasmic-protein fractions from longissimus dorsi (LD) and hind-limb (HL) muscle of piglets. (I) $\mathrm{pH}_{5}$ sarcoplasmic-protein fraction: $\nabla$, Expt 2 LD; $\boldsymbol{\nabla}$, Expt $2 \mathrm{HL}$ (results displaced by $5 \mathrm{~d}$ from the ordinate). (2) Actomyosin: $\odot$, Expt 2 LD;, Expt 2 HL. (3) Actin: +, Expt I LD; $\square$, Expt 2 LD; , Expt 2 HL ( $a$ values $\times 0.67$ ). (4) Myosin: $x$, Expt I LD; $\Delta$, Expt 2 LD; $\Delta$, Expt. 2 HL $(a$ values $\times 0.25)$.

actin (curve 3 ) when multiplied by $1 \cdot 0 / 0 \cdot 67$ become comparable with those obtained for actomyosin (curve 2). The values for myosin (curve $4-\mathrm{LD}$ ) are similarly comparable with those for actin (curve $3-\mathrm{LD}$ ) when both sets of values are multiplied by the appropriate factors, i.e. $\mathrm{I} \cdot 0 / 0 \cdot 25$ and $\mathrm{I} \cdot 0 / 0 \cdot 67$. In this latter case, however, the myosin $a$ values need also to be corrected for counting efficiency $(68 \%)$ as they are expressed as disintegrations $/ 40 \mathrm{~min}$ per $\mu \mathrm{mol}$.

Table I summarizes the respective $k_{\mathrm{s}}$ and $k_{\mathrm{c}}$ values obtained for each of the protein fractions of muscle. These results have been calculated by regression correlation from the semi- $\log$ plots of $a$ shown in Fig. $\mathbf{x}$. It is seen that there is good agreement between experiments and also that the results obtained in Expt 2 for LD muscles do not differ significantly from those for HL muscles. So far as individual protein fractions are concerned, the only combined $k_{\mathrm{s}}$ values which were significantly different from actomyosin were those for $\mathrm{pH}_{5}{ }^{\circ} \mathrm{o}$ sarcoplasmic protein $(P<0.04)$. IMCT and stroma fractions were excluded from this analysis; they are considered separately later.

It is implicit, therefore, that the significant difference between the correlated values of $k_{\mathrm{s}}$ for sarcoplasmic proteins and actomyosin would be similarly reflected in greater values of $a$ for sarcoplasmic proteins on day $\mathrm{I}$, and that $a$ would fall more rapidly in this fraction. This was so when mixed sarcoplasmic-protein and actomyosin values 
were compared (Expt 2 LD): actomyosin $a$ day 1724 , day 2403 , day 3289 ; mixed sarcoplasmic protein $a$; day I 99I, day 2479 , day 3 30r. Unfortunately, further comparisons of sarcoplasmic-protein $a$ values with those obtained for the different myofibrillar-protein fractions are subject to appreciable error as it was noted retrospectively that count values obtained for sarcoplasmic- and plasma-protein extracts were subject to much greater quench. This was possibly due to greater quantities of material having been prepared for analysis. Automatic amino acid analysis failed however to reveal any significant contamination with amino acids other than aspartate or glutamate. Therefore, whereas the values of $k_{\mathrm{s}}$ are comparable with those obtained for the other protein fractions, the results for $a$ are not so easily compared.

It may be concluded therefore that the two major myofibrillar proteins, actin and myosin, are synthesized at the same rate, and since they constitute the major protein fraction of muscle (see Tables 2 and 3 ), that they account for a major proportion of the total amino acid metabolism.

The results obtained in Expt 2 for mixed untreated sarcoplasmic proteins (see p. $3^{6}$ ) for $a$ and $k_{\mathrm{s}}$ were statistically indistinguishable from the values in Fig. $\mathrm{I}$ and Table $\mathrm{I}$ for $\mathrm{pH} 5$ sarcoplasmic proteins. Since the untreated fraction contains plasma serum albumin and the $\mathrm{pH}^{\circ}$ o fraction does not, this observation supports the view that the measured differences in $k_{\tilde{\mathrm{s}}}$ and $k_{\mathrm{c}}$ between sarcoplasmic- and myofibrillarprotein fractions do not result from contamination of the sarcoplasmic proteins with plasma proteins of much higher $a$. Furthermore, independent analyses of mixed plasma proteins for aspartate + glutamate $a$ failed to demonstrate any differences large enough to significantly affect the sarcoplasmic-protein aspartate + glutamate $a$ values and by inference therefore the measured $k_{\mathrm{s}}$ of sarcoplasmic proteins (i.e. plasmaprotein aspartate+glutamate $a$; day I $_{1703}$, day 6748 , day 9498 , whereas mixed sarcoplasmic aspartate + glutamate $a$ (LD); day I 99I, day 6479 , day $930 \mathrm{I}$ ). It has been confirmed (D. J. Millward, personal communication) that these differences in plasma- and sarcoplasmic-protein aspartate + glutamate $a$ are much less than those found in the rat. It would appear, therefore, that in large animals muscle assumes a more important role relative to liver in regulating whole body amino acid metabolism.

In Expt I results were obtained for mixed mitochondrial proteins from biceps femoris muscle. The results $\left({ }_{\mathrm{s}} T_{\frac{1}{2}}=4.23 \mathrm{~d}\right)$ were very similar to those for the $\mathrm{pH} 5$ sarcoplasmic-protein fraction in Expt $2\left(T_{\frac{1}{2}}=4 \cdot 7^{8} \mathrm{~d}\right)$.

It will be noted from Table $\mathrm{I}$ that only results obtained for IMCT treated with $\mathrm{KCl}$ (Expt I) and KI-stroma (Expt 2) have been presented. The reasons for omitting the results for IMCT treated with trypsin (see p. 37) may be considered briefly. It was found that there was an appreciable decrease in the $a$ of aspartate + glutamate in this fraction after treatment with trypsin. This resulted in the calculated ${ }_{\mathrm{s}} T_{\frac{1}{2}}$ and ${ }_{\mathrm{c}} T_{\frac{1}{2}}$ values becoming extremely large $\left({ }_{\mathrm{s}} T_{\frac{1}{2}}>20 \mathrm{~d} ;{ }_{\mathrm{c}} T_{\frac{1}{2}}=\infty\right)$, results which are clearly in error. The loss of radioactivity after treatment with trypsin probably resulted from the extraction of soluble telopeptide material of high $a$, which in these young animals had not been stabilized into the IMCT matrix; this possibility has not been investigated further here. 
Vol. $3^{\text {I }}$

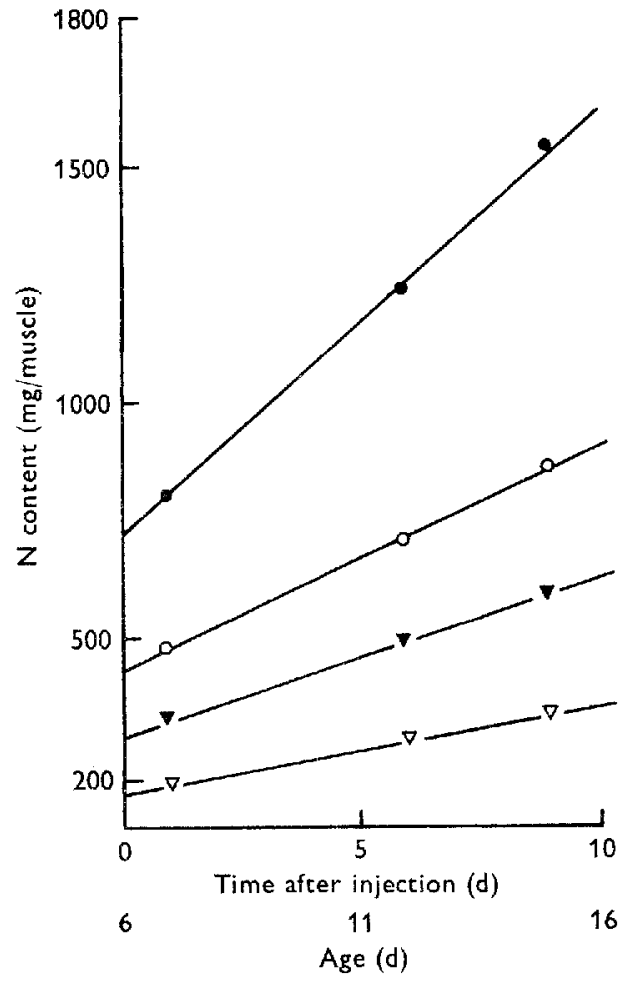

Fig. 2. Growth in total nitrogen contents of subfractions of longissimus dorsi (LD) and hindlimb (HL) muscles of piglets with time. Individual points were derived from results presented in Tables 2 and 3.0 , Myofibrillar $N(H L) ; O$, myofibrillar $N(L D) ; \quad$, sarcoplasmic $N$ (HL); $\nabla$, sarcoplasmic N (LD).

Table 2. Expt 2. Composition of longissimus dorsi muscle of piglets on a fresh-weight basis

Piglet no.

Age at slaughter $(\mathrm{d})$

Time after injection (d)
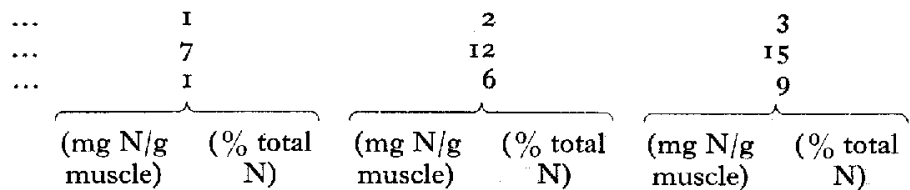

Total N

Total non-protein $\mathrm{N}$

Total protein $\mathrm{N}$

KI protein $\mathbf{N}$

Sarcoplasmic protein N

Myofibrillar protein $\mathrm{N}$

$\begin{array}{rc}24 \cdot 9 & - \\ 3 \cdot 1 & 12 \cdot 4 \\ 21 \cdot 8 & - \\ 18 \cdot 2 & - \\ 5 \cdot 3 & 21 \cdot 3 \\ 12 \cdot 9 & 51 \cdot 8 \\ 3 \cdot 3 & 13 \cdot 3 \\ 98 \cdot 9 & - \\ 35 \cdot 33 & - \\ 84 \cdot 6 & -\end{array}$

$27 \cdot 2$
$3 \cdot 4$
$23 \cdot 8$
$20 \cdot 1$
$5 \cdot 5$
$14 \cdot 7$
$3 \cdot 5$
$99 \cdot 2$
$48 \cdot 43$
$83 \cdot 1$

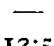

$12 \cdot 5$

$29 \cdot 0$

$3 \cdot 7$

$25 \cdot 3$

$21 \cdot 7$

5.7

16.0

$3 \cdot 5$

$99 \cdot 7$

$50 \cdot 04$

$82 \cdot 1$
Muscle wet weight $(\mathrm{g})$

Water (approx. \%) 


\section{Table 3. Expt 2. Composition of hind-limb muscles of piglets on a fresh weight basis}

\begin{tabular}{|c|c|c|c|c|c|c|}
\hline \multirow[t]{2}{*}{$\begin{array}{l}\text { Piglet no. } \\
\text { Age at slaughter (d) } \\
\text { Time after injection (d) }\end{array}$} & & & & & & $\begin{array}{l}3 \\
5 \\
9\end{array}$ \\
\hline & $\begin{array}{l}\text { (mg N/g } / g \\
\text { muscle) }\end{array}$ & $\begin{array}{c}(\% \text { total } \\
\mathrm{N})\end{array}$ & $\begin{array}{l}\text { (mg N/g } \\
\text { muscle) }\end{array}$ & $\begin{array}{l}(\% \text { total } \\
\mathrm{N})\end{array}$ & $\begin{array}{l}\text { (mg N/g } \\
\text { muscle) }\end{array}$ & $\begin{array}{c}\% \text { total } \\
\mathrm{N})\end{array}$ \\
\hline Total N & $24 \cdot 2$ & - & $27 \cdot 0$ & - & $28 \cdot 3$ & - \\
\hline Total non-protein $N$ & 3.0 & 12.4 & $3 \cdot 4$ & $12 \cdot 6$ & $3 \cdot 5$ & $12 \cdot 4$ \\
\hline Total protein $\mathbf{N}$ & $2 I \cdot 2$ & - & $23 \cdot 6$ & - & $24 \cdot 8$ & - \\
\hline KI protein $\mathrm{N}$ & $19 \cdot 3$ & - & $20 \cdot 9$ & - & $22 \cdot 2$ & - \\
\hline Sarcoplasmic protein $\mathrm{N}$ & 5.7 & $23 \cdot 6$ & $6 \cdot 3$ & $23 \cdot 3$ & $6 \cdot 2$ & $21 \cdot 9$ \\
\hline Myofibrillar protein $\mathrm{N}$ & 13.6 & $56 \cdot 2$ & $14 \cdot 6$ & $54 \cdot x$ & $16 \cdot 0$ & $56 \cdot 5$ \\
\hline Stroma N & $\mathrm{I} \cdot 8$ & $7 \cdot 4$ & $2 \cdot 6$ & $9 \cdot 6$ & $2 \cdot 3$ & $8 \cdot I$ \\
\hline Recovery of $\mathrm{N}(\%)$ & $99 \cdot 2$ & - & $99 \cdot 4$ & - & $99^{\circ} 0$ & - \\
\hline Muscle wet weight (g) & $60 \cdot 78$ & - & $79 \cdot 86$ & - & $97 \cdot 12$ & - \\
\hline Water (approx. \%) & $85^{\circ} \circ$ & - & $83 \cdot 2$ & - & $82 \cdot 5$ & - \\
\hline
\end{tabular}

$\mathrm{KI}$ extraction of muscle to yield stroma protein also appeared to produce erroneous values, for Table I shows that the ${ }_{s} T_{\frac{1}{2}}$ value for the stroma fraction $(6 \cdot 3 \mathrm{~d})$ was considerably lower than that for $\mathrm{KCl}$-extracted IMCT $(8 \cdot \mathrm{I} \mathrm{d})$. This probably reflects the inability of $\mathrm{KI}$ to extract quantitatively any contaminating denatured sarcoplasmic protein of higher $a$ from the IMCT matrix. This would also account for the variability in the contribution of this fraction to the total composition of the muscles (see Tables 2 and 3 ). The contamination, judging from the $a$ values, amounted to more than $40 \%$ on an $\mathrm{N}$ basis. For this reason, catabolic rates shown for IMCT in Table $\mathrm{I}$ are calculated from the $a$ obtained in Expt $\mathrm{I}$ for KCl-extracted IMCT, and the values for mean composition in Expt 2. From the muscle composition values (Tables 2 and 3 ) and growth results (Fig. 2) this would seem to be a reasonable approximation.

The results for skeletal muscle composition presented in Tables 2 and 3 demonstrate that in all but one instance recovery of $\mathrm{N}$ was more than $99 \%$. Freeze-drying and powdering were found to improve sampling and reproducibility, duplicate samples usually agreeing to within $2 \%$ of the mean value. Comparisons with published findings (Dickerson \& Widdowson, 1960) also suggest that freeze-drying has little or no effect upon protein extractability. Nevertheless, consistent differences in muscle-protein composition, unattributable to extraction efficiency, were found both between each of the muscle groups and between individual animals within a group. Presumably these reflect differences in the ages and postnatal development of piglets at slaughter.

\section{DISCUSSION}

The advantage of using the $a$ of aspartate + glutamate to calculate $k_{\mathrm{s}}$ and $k_{\mathrm{e}}$ of muscle proteins has been discussed in detail elsewhere (Millward, 1970 a,b). Garlick $\&$ Millward (1972) have also recently reviewed the validity and applicability of this technique, compared with other methods available for measuring protein turnover. To the author's knowledge, however, there are no published findings for large animal 
species or for individual proteins isolated from skeletal muscle. The values for the pig, obtained by using an experimental procedure similar to that of Millward (I970a, b), make possible some comparisons between species.

It is, however, important to consider first some of the problems encountered in using the method to study protein turnover in animals much larger than rats or mice. The technique depends upon labelling aspartate + glutamate, which also provides important information relating to protein catabolism. However, because of the low incorporation efficiency of ${ }^{14} \mathrm{CO}_{3}{ }^{2-}$ into these residues, very careful analytical procedures are required if adequate reproducibility and accuracy are to be obtained. For example, our recent experience has been that the $\mathrm{CO}_{3}{ }^{2-}$ method precluded accurate measurement of protein synthesis and catabolism in individual muscles and muscle proteins of larger pigs ( $100 \mathrm{~kg}$ ), even though each animal received $\mathrm{I} 2.5 \mathrm{mCi}^{14} \mathrm{CO}_{3}{ }^{2-}$, because the $a$ of aspartate + glutamate residues were even lower than those recorded here. Another problem encountered has been that methods adopted for the isolation of muscle proteins and for measuring muscle-protein composition are both timeconsuming and difficult to reproduce exactly. For these reasons, no attempts were made to isolate individual proteins from the sarcoplasmic-protein extract.

Despite these problems, it has been demonstrated statistically that sarcoplasmic proteins are synthesized more rapidly than myofibrillar proteins. The $k_{\mathrm{c}}$ of mixed sarcoplasmic proteins was also greater than that of actomyosin. These results are furthermore not confounded by contamination of the sarcoplasmic-protein fraction with plasma proteins of much higher $a$ since care was taken to remove the latter during preparation.

The apparent anomaly shown in Fig. I, which indicates the $a$ values for sarcoplasmic proteins to be little greater at day $\mathbf{I}$ after injection of isotope than those for actomyosin or actin, although the $k_{\mathrm{s}}$ for sarcoplasmic proteins was statistically significantly greater, probably reflects small errors in amino acid analyses and differences in counting efficiencies. However, as for each individual protein fraction similar quantities of material were prepared, analysed in batches and shown to give consistent results (see p. 37), the values for $k_{\mathrm{s}}$ and $k_{\mathrm{c}}$ of the different proteins should be compared, rather than those for $a$. The similar results obtained from the two separate experiments, for each of the different protein fractions (see Table I), suggest this conclusion to be more correct. Nevertheless, allowing for greater variability in $a$, the failure to demonstrate differences between sarcoplasmic- and plasma-protein $a$ values as great as those found in the rat (D. J. Millward, personal communication) supports in part the hypothesis (Munro, 1969; Millward \& Garlick, 1972) that, in animals of greater mature body size than rats or mice, muscle assumes a more important role relative to liver in regulating whole body amino acid metabolism.

The rates of synthesis and catabolism obtained for mixed myofibrillar (actomyosin)and $\mathrm{pH}_{5}$ sarcoplasmic-protein fractions are very similar to those found for $100 \mathrm{~g}$ rats by Millward (1970 a, b) and Gan \& Jeffay (197I). These similarities may, however, be purely fortuitous, since $100 \mathrm{~g}$ rats are far more mature than the young piglets investigated here, and have presumably nearly reached a plateau level of synthesis and catabolism, whereas the piglets certainly have not. 
The good agreement between Expts $\mathrm{I}$ and 2 and failure to demonstrate significant differences in $k_{\mathrm{s}}$ between LD and HL muscle in Expt 2 are interesting, since anatomical dissections of pigs from birth to $40 \mathrm{~kg}$ (unpublished observations) indicate that $\mathrm{HL}$ muscles collectively possess marginally greater growth coefficients than LD. To what extent, therefore, the differences in $k_{\mathrm{c}}$ for LD and $\mathrm{HL}$ are significant (see Table $\mathrm{I}$ ) or reflect summed errors in the respective analytical procedures would seem to be an important question, because limits to the size and rates of growth of muscles may not only be due to differences in $k_{s}$, and presumably due to differences in coding, but may also be controlled by differing specific activities of skeletal-muscle cathepsins and proteases, presumably also coded differently. Clearly some independent assessment of protein catabolism (e.g. 3-methyl-histidine entry rate) would be needed to assess this possibility further.

The fact that differences between $k_{\mathrm{s}}$ and $k_{\mathrm{c}}$ measure net synthesis (i.e. growth), and changes in both $k_{\mathrm{s}}$ and $k_{\mathrm{c}}$ will therefore influence growth is interesting, for results we have obtained from two roo kg pigs (see p. 43) killed $\mathrm{I}$ and $6 \mathrm{~d}$ after injection of $\left[{ }^{14} \mathrm{C}_{\mathrm{Na}_{2}} \mathrm{CO}_{3}\right.$, gave, with mixed myofibrillar-sarcoplasmic proteins (10 mM-NaOH, pH 8 extracted), ${ }_{s} T_{\frac{1}{2}}$ of $4.2,9.0$ and $6.2 \mathrm{~d}$ in psoas major (PS), biceps femoris (BF) and semimembranosus (SM) muscles respectively, i.e. values which were very similar to those obtained with piglets. In view of the few observations made $(n)$, the low aspartate + glutamate $a$ values and relatively large standard errors (PS day $\mathrm{x} ;{ }_{5} \mathrm{I}^{1} 6 \pm 0.3$ $n=2 ;$ day $6 ; 57 \cdot 0 \pm 4 \cdot 3 n=3 ;$ BF day I $; 1777 \pm 8 \cdot 3 n=7 ;$ day $6 ; 82 \cdot 8 \pm 7 \cdot 7 n=8 ; \mathrm{SM}$ day I; I I $5.9 \pm 4.8 n=4$; day $6 ; 65^{\circ} 3 \pm 0.8 n=2$ ) these results must however be considered with caution. They do nevertheless indicate a field of study warranting further investigation.

The finding that, in skeletal muscle, myosin, actin and crude actomyosin all appear to be synthesized and catabolized at similar rates is in excellent agreement with the findings of Chain \& Sender (1972). They were unable to show any differences in the $a$ of cardiac myofibrillar proteins after separation on sodium dodecyl sulphate-acrylamide gel columns when the proteins were labelled by constant infusion rather than by the single-shot labelling technique (cf. Schimke, 1970; Young, 1970).

The wide discrepancies in results obtained for $k_{\mathrm{s}}$ and $k_{\mathrm{c}}$ of IMCT when different extraction procedures were followed have been noted already. They confirm the difficulty of identifying the composition of mixed protein fractions from muscle. The extractability of IMCT seems to be particularly affected by the stage of development and age of the animal. This arises no doubt as a consequence of changes in the physical and chemical constitution of collagen which are physiologically and chronologically ordered (Shimokomaki \& Bailey, 1971).

I thank Dr J. R. Bendall for his critical examination of the manuscript and Miss G. Wells for skilled technical assistance. 


\section{REFERENCES}

Chain, E. B. \& Sender, P. M. (1972). Biochem. F. 129, 13 P.

Cheah, K. S. (1970). FEBS Letters 1o, 109.

Dickerson, J. W. T. \& Widdowson, E. M. (1960). Biochem. 7. 74, 247.

Gan, J. C. \& Jeffay, H. (1971). Biochim. biophys. Acta 252, 125.

Garlick, P. J. (1969). Nature, Lond. 223, 61.

Garlick, P. J. \& Marshall, I. (1972). F. Neurochem. 19, 577.

Garlick, P. J. \& Millward, D. J. (1972). Biochem. F. 129, I P.

Helander, E. ( 1957). Acta physiol. scand. 4r, Suppl. no. I4r.

Helander, E. (196I). Biochem. $7.78,478$.

Millward, D. J. (1970a). Clin. Sci. 39, 577 .

Millward, D. J. (1970b). Clin. Sci. 39, 59I.

Millward, D. J. \& Garlick, P. J. (1972). Biochem. F. 129, 2 P.

Mohr, V. (I970). Physical and chemical properties of intramuscular connective tissue. PhD Thesis, University of Aberdeen.

Munro, H. N. (1969). In Mammalian Protein Metabolism Vol. 3, Ch. 25 [H. N. Munro, editor]. London and New York: Academic Press.

Partridge, S. M. \& Brimley, R. C. (I949). Biochem. F. 44, 513.

Schimke, R. T. (I970). In Mammalian Protein Metabolism Vol. 4, Ch. 32 [H. N. Munro, editor]. London and New York: Academic Press.

Shimokomaki, M. \& Bailey, A. J. (I97I). Proc. Eur. Mtg Meat Res. Workers 17 pp. 624-647.

Waterlow, J. C. \& Stephen, J. M. L. (1968). Clin. Sci. 35, 287.

Yernm, E. W. \& Cocking, E. C. (1955). Analyst, Lond. 80, 209.

Young, V. R. (1970). In Mammalian Protein Metabolism Vol. 4, Ch. 43 [H. N. Munro, editor]. London and New York: Academic Press. 